Insight, part of a Special Feature on The influence of human demography and agriculture on natural systems in the Neotropics

\title{
Urban Forest and Rural Cities: Multi-sited Households, Consumption Patterns, and Forest Resources in Amazonia
}

\author{
$\underline{\text { Christine Padoch }}^{1}, \underline{\text { Eduardo Brondizio }}^{2}, \underline{\text { Sandra Costa }}^{3}, \underline{\text { Miguel Pinedo-Vasquez }}^{4}, \underline{\text { Robin R. Sears }}^{5,6}$, and $^{\text {Endrea Siqueic }}$ \\ Andrea Siqueira $^{7}$
}

\begin{abstract}
In much of the Amazon Basin, approximately $70 \%$ of the population lives in urban areas and urbanward migration continues. Based on data collected over more than a decade in two long-settled regions of Amazonia, we find that rural-urban migration in the region is an extended and complex process. Like recent rural-urban migrants worldwide, Amazonian migrants, although they may be counted as urban residents, are often not absent from rural areas but remain members of multi-sited households and continue to participate in rural-urban networks and in rural land-use decisions. Our research indicates that, despite their general poverty, these migrants have affected urban markets for both food and construction materials. We present two cases: that of açaí palm fruit in the estuary of the Amazon and of cheap construction timbers in the Peruvian Amazon. We find that many new Amazonian rural-urban migrants have maintained some important rural patterns of both consumption and knowledge. Through their consumer behavior, they are affecting the areal extent of forests; in the two floodplain regions discussed, tree cover is increasing. We also find changes in forest composition, reflecting the persistence of rural consumption patterns in cities resulting in increased demand for and production of açaí and cheap timber species.
\end{abstract}

Key Words: afforestation; Amazonia; deforestation; rural-urban migration; urban-rural interactions

\section{ENTERING THE URBAN MILLENNIUM}

The United Nations Population Fund (UNFPA) estimates that, in 2008, for the first time in history, more than half the world's human population is living in urban areas (UNFPA 2007). The pace of rural-urban migration has been rapid throughout the $20^{\text {th }}$ century, but over the last few decades, it picked up markedly and is expected to continue to surge in coming years.

Although cities around the globe are growing, populations in developing countries are urbanizing most rapidly. In the future, new urbanites will increasingly be found in developing countries; a great many of them will be poor. Since 1970, the growth rate of slums generally has outpaced that of urban areas (Davis 2006:17). The United Nations Human Settlements Programme (UN-HABITAT) reports that, in 2001, about $32 \%$ of the world's urban population lived in slums; in developing countries, this percentage stood at $43 \%$ (UN-HABITAT 2003).

The movement of rural people to cities and the growth of those urban areas are processes that have historically had important impacts on rural environments, including forests. How rural-urban migration specifically affects forest cover in tropical countries has recently received considerable attention (Lambin et al. 2001, Aide and Grau 2004, Wright and Muller-Landau 2006, Garcia et al. 2007, and others). Urbanization will lead to recovery of substantial areas of tropical forest if migration drains the rural zones of population and returns abandoned farmland to forest, as occurred in northern Europe and North America, as well as in some areas of the Caribbean and South America

\footnotetext{
${ }^{1}$ The New York Botanical Garden, ${ }^{2}$ Dept. of Anthropology, Anthropological Center for Training and Research on Global Environmental Change, Center for the Study of Institutions, Population, and Environmental Change, Indiana University, ${ }^{3}$ Laboratory of Urban and Regional Planning, University of Vale do Paraiba - SP, ${ }^{4}$ Center for Environmental Research and Conservation and Dept. of Ecology, Evolution, and Environmental Biology, Columbia University, ${ }^{5}$ Center for Environmental Research and Conservation, Columbia University, ${ }^{6}$ The School for Field Studies, ${ }^{7}$ Center for Latin American \& Caribbean Studies and ACT - Dept. of Anthropology, Indiana University
} 
(Grau et al. 2003, Aide and Grau 2004, Wright and Muller-Landau 2006). In some tropical countries where urbanward migration is taking place, and small farmers have decamped, researchers have noted, however, that forests do not increase. Rather, many smallholder farms are replaced by a few largescale producers - in Latin America, often cattle ranches (Rudel et al. 2002) - or by new migrant farmers who simply replace those who left (Fearnside 2005).

Elsewhere in tropical regions undergoing substantial urbanization, migration results in neither dramatic decreases in rural populations nor abandonment of crop production, but does lead to growth of forest cover. In these zones, both the extent of tree cover and the composition of forests may change because of shifts in the type of crops produced and the kind of resource management employed (Rudel et al. 2002). The prevalence of such trends, Rudel notes, may reflect substantive differences between the patterns of urbanization and industrialization in present-day Latin America and Southeast Asia and those that prevailed in North America and Europe when their "forest transitions" occurred. Among such important dissimilarities are new forms of migration and household economic strategies reflecting improvements in communication and transportation in many poor countries of Asia and Latin America. But, although relocation may be easier, good jobs in growing cities remain scarce, making exclusively urban employment and residence a risky strategy. Researchers worldwide have pointed out that rural-urban movements in poorer countries are now typically impermanent or circular, and multi-sited or dispersed households that continue rural production yet also depend on off-farm, often urban, incomes, are increasingly the norm (Kruger 1998, Rudel et al. 2002, Tacoli 2002, Rigg 2003, Dufour and Piperata 2004).

Based on our research in several regions of Amazonia, in this paper, we suggest that complex demographic flows between rural and urban areas, and multi-sited households characterize communities in the Amazon floodplain, and these characteristics are affecting both the extent and the nature of forests in these long-settled areas of Amazonia. Our data suggest that many urbanward migrants in Amazonia are not really absent from rural zones; they remain members of households with livelihood activities in both rural and urban environments. Whatever their primary residence, these mobile Amazonians continue to participate in rural-urban networks, maintain their rural-based preferences and needs, and retain their knowledge of rural resources and products.

Several specific mechanisms, other than land abandonment, through which rural-urban shifts affect rural communities and environments, have been described. These include the remitting of funds to rural household members (Tiffen et al. 1994, Hecht and Saatchi, 2007), changes in rural labor availability (Preston 1989, Rudel et al. 2005), variation in the gender composition of households (David 1995, cited in McDowell and de Haan 1997), and the shifting demands urban consumers make on agricultural and other rural resources (Brondizio et al. 2002, Tacoli 2002). In this paper, we suggest that, as consumers, new city dwellers in the Amazon have significantly changed urban markets and consumption patterns for forest products despite their poverty. We use examples of a staple food and construction materials to illustrate how the consumer choices of recent urbanites are affecting rural landscapes, specifically forest cover and the nature, structure, and composition of Amazon forests.

\section{THE URBANIZATION OF AMAZONIA}

The complex history of urbanization in the Brazilian Amazon has interested scholars since at least the 1950s (Wagley 1953, Becker 1985, Browder and Godfrey 1997, Vicentini 2006). Regional urbanization reflects an interaction, on one hand, of the region's economic and demographic history and long-standing connections to global markets, and, on the other, a strong presence of the state. Following a vision of national integration dating back more than half a century, the federal government of Brazil has repeatedly articulated and executed strategies of colonization, resource exploitation, and economic development. These efforts spurred migration to Amazonia, marked by waves of colonization of agrarian settlements and rural towns. High rates of turnover in colonization areas, in turn, accelerated urban expansion. As Becker (1988) observed, urbanization in the Brazilian Amazon-and this also applies to neighboring Peru-is a complex and multi-faceted process that comprises the growth of older centers (such as Belém and Manaus in Brazil and Iquitos in Peru), the formation of new ones (such as Jiparaná in Rondônia, and Nueva Cajamarca in Peru's San Martin region), as well as the reproduction of 
numerous small and medium towns throughout the region.

By 2000, the national census indicated the population of Brazil's "Amazônia Legal" (i.e., the states of Amazonas, Para, Acre, Tocantins, Mato Grosso, Maranhão, Amapá, Rondônia, and Roraima) was already about $70 \%$ urbanized, compared with $82 \%$ for the country as a whole. Comparing the broad process of urbanization in all of Brazil to that of its Amazonian region, we note that Amazonia's urban growth began later (in the 1970s vs. the 1950s for Brazil), but that in recent decades, the Amazonian urbanization rate has increased rapidly and is approaching that of the country as a whole. Census data show the urban population of all Brazil increased by $82 \%$ between 1970 and 2007. The urban population of Amazônia Legal grew 430\% during this same period (Instituto Brasileiro de Geografia e Estatística (IBGE) 2007). Whereas Brazil has mostly experienced steadily declining rates of population increase, the Amazon region continued to see recurrent spikes and contractions in growth rates, reflecting waves of migration to different parts of the region.

In the Peruvian national census of 2005, the populations of the vast departments of Loreto and Ucayali, which cover the greatest portion of the lowland Amazon region, were already 63\% and $72 \%$ urban, respectively, in a country where almost $75 \%$ of the total lived in cities (Instituto Nacional de Estadística e Informática (INEI) 2007). This urban predominance largely reflects rapid growth of Peru's two largest Amazonian cities, Iquitos and Pucallpa, which increased in size dramatically beginning in the 1960s. Due to massive immigration from rural areas of Loreto, the population of Iquitos more than quadrupled between 1961 and 1993 (Santos-Granero and Barclay 2000:286). In the same period, the population of Pucallpa along the upper Ucayali River increased more than six-fold (Santos-Granero and Barclay 2000:286).

As we describe in more depth for Pucallpa below, urban immigrants tend to reside in hastily constructed, grossly substandard housing in urban settlements that are opportunistic, illegally occupying terrain formally owned by either private or public entities. Although infrastructure tends to improve with time, access to basic urban services in virtually all of these settlements is very limited. In 1991, in Belém and Manaus, respectively, 25\% and $35 \%$ of households were not connected to the municipal water system and only $2 \%$ were connected to sewers (IBGE 1990), a situation that resembles the rural areas from which immigrants come where such services are generally absent (Perz 2000).

Brazilian urban geographer Bertha Becker (2005) has noted the need to understand urbanization processes in a broader context, and suggests that mere numbers showing the growth of populations in cities and towns give an inadequate picture of the extent and meaning of urbanization in Amazonia. The transformation of the values of Amazon society are another, if less easily calculated, measure of urbanization. Becker famously describes all Amazonia as an "urbanized forest." In similar fashion, we argue in this paper that family networks spanning rural and urban areas create venues for the circulation of goods, access to employment, education, and health services. These networks make urban areas an intrinsic part of an expansion of the rural, and vice versa.

\section{RURAL, URBAN, AND IN-BETWEEN}

Despite the dramatic growth of Amazonian urban places mentioned above, it is important to note that the urbanization of Amazonia as a process has not been simple, linear, or unidirectional. Demographic exchanges between rural and urban areas in recent decades have included shifts that temporarily reversed present urbanward trends (Paganoto 2007). A recent example is the negative growth of Boa Vista, capital of the Brazilian state of Roraima, which saw a 4\% drop in population between 1995 and 2000, as government-sponsored rural resettlement programs pulled the urban poor back to the countryside, temporarily reversing urbanization trends (Sathler et al. 2007). Similar shifts in Peruvian Amazonia occurred in the 1970s and early 1980s when large numbers of men-both rural and urban dwellers-found long-term employment in distant forests where oil exploration and pipeline construction was underway.

The numbers and narratives describing the ebb and flow of people present, however, a deceptively simple picture of demographic relationships between urban and rural places. Although people in Amazonia are classified as residing in either urban or rural places, researchers around the world have noted (Tacoli 2002, Smit 1998, Rigg 2002, 2003) that the distinction is often difficult to make. 
Whereas rural areas in Africa and Asia are becoming increasingly "de-agrarianized" and urban, a trend of "ruralization" of cities and towns has also been described, with rural lifestyles, attitudes, and occupations persisting in even large conurbations (Kruger 1998).

Categorization of people, households, or even communities in Amazonia as rural or urban is difficult as rural and urban spaces and peoples are inextricably linked in numerous ways (Wagley 1953, Nugent 1993, WinklerPrins 2002, WinklerPrins and de Souza 2005, Siqueira 2006). A great many newly urban households are "multi-sited," "multilocal," or dispersed, maintaining houses and, commonly, economic activities in rural areas as well as in the city. Data obtained through interviews in five rural communities in the Brazilian state of Amapá confirm these findings: of the 483 households censused in the five villages of Foz de Mazagão, Ipixuna, Bacaba, Santo Antônio, and Lontra Pedreira in 2005, 402 (83\%), have a house in the state's largest cities of Macapá or Santana, or in the district capital, Mazagão Novo (PinedoVasquez and Padoch 2008).

Although multi-sited households are not new to Amazonia, recent changes in communications and transportation, markets, and labor opportunities have greatly amplified the prevalence of this residence and economic pattern (Stearman 1985). Nugent (1993) described how several such large extended families, or "kindreds," in the region of Santarém maintained firm residential bases in both city and village, relying on the resources of both. More recently, WinklerPrins $(2002,2006)$ has described smaller groupings or households that maintain such dual residence patterns in the Santarém area. She describes not only frequent demographic movements between urban and rural places, but also complex and multi-functional networks of support and interaction that link residents of Santarém with their rural kin in an "economy of affection" (WinklerPrins and de Souza 2005). Two-way flows of food and other resources - of people, as well as of news and knowledgereinforce this "economy of affection," continue to blur rural-urban distinctions, and render ruralurban migration a drawn-out process rather than a simple event.

Two case studies of urban and rural change from two widely separated areas of Amazonia (see Fig. 1) serve to illustrate our points. Each case study, based on field research we have been conducting for over a decade (see Appendix 1 for a description of research sites and summary of methods), involves "ribeirinho" (in Brazil, "ribereño" in Peru) peasant households and communities that occupy and manage sites in the "várzea," or floodplains of the Amazon and other rivers.

\section{AÇAÍ: RURAL TASTES AND URBAN MARKETS}

The floodplains of the Brazilian Amazon in the states of Amapá and Pará are areas where the "deforestation frontier" passed centuries or decades ago, but where important land-use and land-cover change continues (Perz and Skole 2003). The ribeirinhos comprise a mixed population of residents native to the estuary and long-settled migrants from other regions and environments. Households are typically multi-sited, combining production activities with labor in both rural and urban settings. In rural areas, families engage in diverse production activities, including small-scale swidden agriculture, agroforestry, forest management for timber and non-timber products, fishing and shrimping, cattle and buffalo ranching, and hunting. The rural landscape comprises a mosaic of ranches, villages, farms, gardens, isolated houses, abandoned house sites, and young and old secondgrowth forests. The city is important to families as a center for education, health care, and employment, and it is where rural families must go to collect pension payments and other government benefits.

Recent government census data show most estuarine municipalities with a majority of families still living in rural areas (IBGE 2007), but our field data indicate that most rural households interact with and depend on urban areas very frequently. A recent unpublished survey we carried out among 262 households (including 2166 individuals) in seven rural communities in Ponta de Pedras, Pará (see Fig. 1), indicates that $41 \%$ of individuals who were considered members of these rural households actually live in the city. The same survey indicates that over $95 \%$ of individuals go to town at least once a week. Preliminary data from an ongoing survey of urban households show similar dependence of town residents on the rural environment.

Frequent movements between village and city in the estuary commonly take many hours of travel by boat 
Fig. 1. Map of research sites.

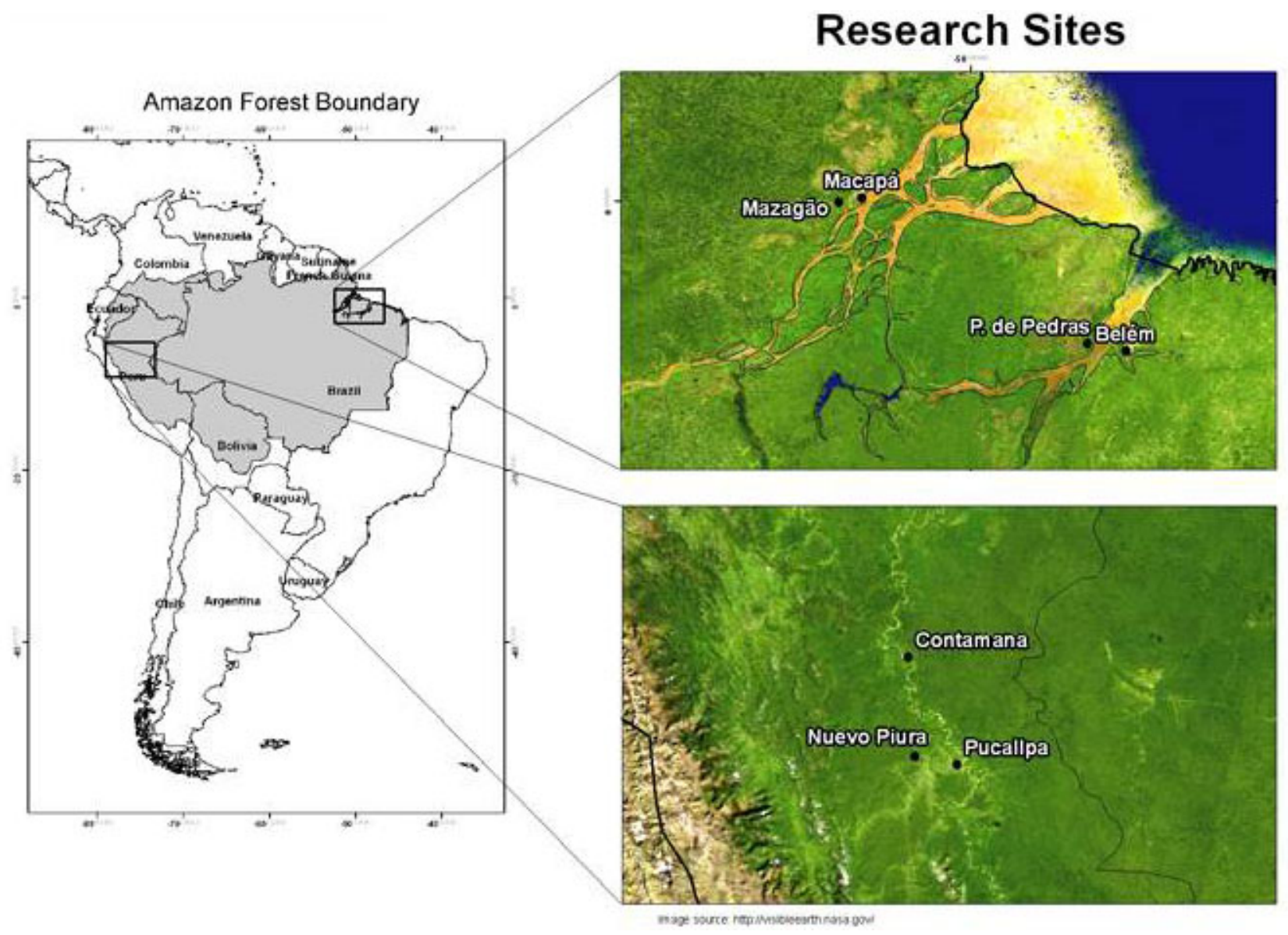

and/or bus, but in most places, travel has become increasingly convenient. Twenty years ago, a trip from Ponta de Pedras to the city of Belém, for instance, could be done only once a week in a cattle boat and took 5 to 6 hours or more; today, two competing boats make the daily journey in 2 to 4 hours. From our Mazagão River research sites in Amapá, villagers now reach the small district capital of Mazagão Novo in about 3 hours and the regional cities of Santana and Macapá in an additional 2 hours.

The estuarine region is characterized by highly dynamic cultural and natural landscapes. Global market transformations, migration, and dislocation of rural and urban populations, and social institutions and networks have played important roles in shaping these landscapes by creating demands for certain products and services at distinct historical periods and effecting fluctuations in forest cover (Pinedo-Vasquez et al. 2002a, Perz and Skole 2003, Brondizio 2006). The estuary is home to Amazonia's historically preeminent city, Belém, Amapá's state capital, Macapá (pop. 345 000), and a series of secondary urban areas mostly accessed by river or air. Although it has recently been eclipsed by Manaus as the Basin's largest city, Belém registered meteoric growth over the last several decades, increasing in population from about 300 000 residents in the 1950 s to over 2 million in the metropolitan area today. Much of that growth was a result of rural families migrating or sending members from the islands, floodplains, and small towns of the estuary, an area traditionally settled by ribeirinhos with distinct rural culture, including food-consumption patterns (Murrieta et al. 1999). 
Our survey, referenced above, indicates that 25\% of household members who left the rural area went to Belém.

The impacts of international market demands on Amazon environments, including markets for rubber(Weinstein 1983, Barham and Coomes 1994) and timber(Bierregard et al. 2001) have been widely discussed, but changes in demand for low-cost, distinctly regional staple foods in an urbanizing Amazonia are also important. The fruits of açaí (Euterpe oleracea), a palm native to the Amazon estuary and extensively managed in mixed forestry and agroforestry systems by farmers, have been an important food in the Amazon estuary since preColumbian times. Until the 1970s, however, when urbanward migration surged in the region, the consumption of açaí was invariably a sign of rural residence and rural tastes, eaten in urban areas only as an occasional treat, usually dessert (Strudwick and Sobel 1988).

Açaí consumption is no longer just a rural habit. Reports indicate that consumption of açaí juice in Belém rose from $90000 \mathrm{~L} /$ day in the late 1980s to an estimated $400000 \mathrm{~L} /$ day in the late 1990s (Mourão 1999, Rogez 2000, IBGE 1974-2003), an increase largely mirroring urbanization rates. This figure implies an estimated consumption of more than 60 L/person/year, or as noted by Rogez (2000), twice the volume of milk consumed in Belém. Families with the lowest level of income consume the largest amount of this food, buying and eating it fresh twice daily as a staple. Poullet (1998) estimates that daily consumption in another smaller estuarine city, Macapá, ranges from 27000 to 34 $000 \mathrm{~L}$.

The boom in açaí consumption and production represents perhaps the most impressive case of a rural food both supporting a growing, low-income urban population, and spurring the intensification and expansion of a forest-based production system throughout the estuary. In contrast to earlier urban dwellers, when ribeirinhos established urban residence in large numbers, they brought and maintained their açaí habits. In addition to providing affordable nourishment, açaí adapted well to an urban lifestyle based on opportunistic work and the informal economy. The preference for açaí by the urban poor, and its importance as a cultural food provided continuity and security to a population living with the uncertainties of an informal urban economy. Açaí continues to have important symbolic value as nourishment that is both familiar and plentiful for the underprivileged, both the recently rural and those who always lived in cities. Açaí has become not only an urban food, but a "fashionable" one as well (Brondizio 2008.)

As açaí has gained importance as a food during the last 30 years, the Amazon estuary has experienced what Hiraoka (1994) called "açaízation" or the expansion of açaí production in estuarine ecosystems. Over the past two decades, farming in the region has shifted from predominantly annualcrop agriculture to forest-based production systems centered on açaí fruit, heart of palm, and managed and unmanaged forestry (Pinedo-Vasquez and Padoch 2008). This region, which corresponds in part to the "settled" zone discussed by Perz and Skole (2003) has, contrary to much of the rest of the Amazon, recently experienced net afforestation and decreasing rates of forest clearing over the past several decades (Brondizio 2008; also see Appendix $1)$.

Within a 10-km radius around the of Marajó Island town of Ponta de Pedras, the area of intensive açaí agroforestry increased from around 1100 ha in 1985 to around 2150 ha in 2000 , and we estimate it now occupies more than 4000 ha (see Appendix 1). This last estimate represents more than $75 \%$ of the total area of floodplain forest in the area analyzed. At the community level, riverine communities have $75 \%$ or more of their territories under forest cover mostly managed for açaí production, whereas upland communities with a history of pasture and mechanized agriculture experienced a doubling of area in secondary vegetation over the past decade when these activities were abandoned in favor again of agroforestry. Similar rates of regrowth characterize communities previously dedicated to small-scale manioc cultivation (Brondizio 2006, 2008; see also Appendix 1).

The expansion of açaí agroforestry in the Amazon estuary has had varying impacts on forest biodiversity. Açaí palms are relatively abundant in estuarine floodplain forests, varying in density and distribution depending on environmental and anthropogenic factors. Different management and planting strategies transform these areas into açaí agroforestry, or in local terms, "açaizais." The term encompasses stands under different intensities of management, population densities, structures, species diversity, and composition. Although at the plot level, one may observe a decline in tree species 
diversity in the açaizais compared with unmanaged floodplain forest, a broader landscape view including plots at different levels of management may show an increase of tree species diversity (Brondizio 2008). As a number of researchers have pointed out, the composition of forests in many instances of "forest transition" is highly variable, ranging from plantations of exotics to diverse forests, and often bear little resemblance to what existed before recent deforestation (Perz and Skole 2003, Rudel et al. 2005, Farley 2007).

\section{BUILDING SQUATTER SETTLEMENTS: FORESTRY BY THE POOR FOR THE POOR}

At almost the other end of the Amazon Basin, along the Ucayali River in Peru (see Fig. 1), an influx of cheap agricultural products to Amazon cities from outside the region has led to a decline in the agricultural sector and the loss of an important source of income for smallholders (Pinedo-Vasquez et al. 2002b). At the same time, however, increasing urbanization, especially the growth of squatter settlements in Pucallpa and other cities as distant as Lima, has created demand for inexpensive construction materials. The economic growth of small urban centers, such as provincial capitals, has added to that demand. More than half the population of Pucallpa, the second largest city of the Peruvian Amazon, resides in informal or squatter settlements, known as "asentamientos humanos" (AA.HH.). According to a director of a grassroots organization representing inhabitants of many AA.HH., the "Comité Unificado" of the "Federación de Asentamientos Humanos" of Pucallpa and neighboring Yarinacocha, by mid-2007 there were 579 named and organized squatter settlements in the urban area. Some AA.HH. date from the 1970s and have been legalized, with title granted to all residents. The great majority of AA.HH. residents however, remain members of illegal or extra-legal settlements. Reflecting the precariousness of many settlements and the poverty of their residents, dwellings are mostly built by the squatters themselves of cheap wood, palm thatch, as well as plastic sheeting, and other inexpensive materials. Of 438 households surveyed in 42 AA.HH. in Pucallpa and Yarinacocha, we found that 285 houses (65\%) had walls made of "bolaina" (Guazuma crinita), a fast-growing timber species found in agricultural fallows; many were framed with "capirona" (Calycophyllum spruceanum), another prolific fallow species.

Timber-rich fallows exist throughout Amazonia. The highly agrodiverse landholdings of rural smallholder farmers, with patches of species-rich fields, fallows, housegardens, and forest, allow for a high degree of flexibility in what they produce as well as in the volume of production (PinedoVasquez et al. 2002b, Padoch and Pinedo-Vasquez 2006). Rural smallholder farmers in Peruvian Amazonia, as elsewhere, have responded to the growing demand for timber and other forest-based products in regional cities by shifting their emphasis from commercially oriented crop production to a combination of smaller scale subsistence agriculture and management of forest products, especially of fast-growing timbers.

Along the Ucayali, downriver from Pucallpa, we have documented a broad decline in the numbers of production units dedicated to agricultural cash crops and mature forests, and a corresponding increase in units dedicated to complex agroforestry and managed secondary forest systems, subsumed under the "fallows" category (Table 1). Similar to the case on the Brazilian estuary described above, this trend has resulted in an increase in forest cover in traditionally agricultural areas (see Appendix 1).

The increased demand for cheap construction materials has resulted in a significant decrease in the average size of annually cropped fields and a corresponding increase in the size of fallows (Table 2). Data collected in 2007 from a sample of 39 landholdings in two districts along Peru's Ucayali River show that all households maintain fallows, with an average of 2.4 fallow units per landholding; $86 \%$ of these fallows contain timber (see Appendix $1)$.

As the demand for fallow timber is rising, farmers are managing for timber production on their landholdings. Farmers produce timber in agricultural fallows by protecting the natural regeneration of fast-growing species at the end of the cropping cycle and by enriching the established fallows with slow-growing species. This pattern of concurrent management of annual and tree crops (Padoch and Pinedo-Vasquez 2006) allows for the establishment of tree saplings on cleared land before weedy second growth begins to dominate and overtake the slower growing trees. In some cases, 
Table 1. Changes over 20 years in average area of four types of land-use units on 47 family landholdings near Contamana from 1986 to 2006.

\begin{tabular}{lccc}
\hline \hline Area under land use (ha) & 1986 & 1996 & 2006 \\
\hline Average landholding & 29 & 27 & 28 \\
Forests & 7 & 6 & 3 \\
Fallows & 5 & 12 & 18 \\
Fields & 8 & 3 & 2 \\
Pastures & 9 & 6 & 5 \\
\hline
\end{tabular}

farmers have ceased planting semiperennial crops such as bananas in fields where natural regeneration of timber trees is healthy.

Under this fallow management system, bolaina can grow in dense, monodominant stands, with upward of 1200 trees/ha in a young fallow ( $<3 \mathrm{yr})$. Once the stand is 4 years old, the bolaina, which can attain a diameter of $25 \mathrm{~cm}$ at breast height (dbh) by then (Weber and Sotelo Montes 2008), can be harvested for production of "tablillas" or small boards, a form of timber used by AA.HH. residents. Our survey of landholdings revealed that, with little management, farmers have an average of 200 commercial-sized trees $(\geq 25 \mathrm{~cm} \mathrm{dbh})$ per hectare. Intensively managed stands can yield 500 commercial trees per hectare, either for clearcutting in a single year or as three harvests 2 years apart with an average yield of 150 commercial trees per harvest.

Timber for construction is one of the most important products of fallow management systems (Sears and Pinedo-Vasquez 2004). Simple house construction demands a number of products, including poles, tablillas, and plywood. Each product can be made of several different species, which allows for the management of a diversity of timber species in fallows. In our survey of fields and fallows, a total of 30 useful tree and palm species were found, 17 of which are timber species, six fruits, and the rest other utilitarian species. One farmer had all 17 timber species growing in his managed fallow.
The sale of fallow timbers can be very profitable, depending on access to labor, transportation, and permits. Increasingly, bolaina- and capirona-rich fallows are becoming the main source of income for smallholders affected by low prices for traditional agricultural crops. Farmers calculate that selling timber from managed fallows yields more profit than raising cattle in the same area. A single hectare of bolaina under minimal management, yielding 200 trees per hectare at year 4, can net US\$1300 in profit for the producer (Table 3). More intensive management can yield over $\$ 3000$, and a wellmanaged fallow can yield three harvest cycles, each 2 years apart, netting on average $\$ 1000$ per harvest. Data collected in the Pucallpa markets in 2007 show that the price of 100 tablillas of bolaina lumber has more than tripled between 2004-when bolaina tablillas first emerged as a market item-and 2007, from $\$ 16$ to $\$ 53$ per 100 tablillas. Likewise the price has almost doubled in Lima over the same time frame, from $\$ 50$ to $\$ 88$ per 100 tablillas, indicating that demand for tablillas has been increasing in coastal cities that are also experiencing an influx of poor rural immigrants.

The transformation of fallow timber to construction lumber useful in the AA.HH. mostly occurs in rural areas, with the use of portable sawmills. The mills are usually owned and operated by rural residents. However, their success depends on the political and economic backstopping of an urban associate, without which they have little chance of obtaining 
Table 2. Average area and number of land-use types per landholding and presence of timber in smallholder properties in Contamana and Nuevo Piura, Peru, in $2007(n=39)$.

\begin{tabular}{lcccc}
\hline \hline Land use types & Total area (ha) & Number of units & $\begin{array}{c}\text { Number of units with } \\
\text { timber species present }\end{array}$ & Area (ha) with timber \\
\hline Fallow & 12.8 & 9 & 6 & 8.4 \\
Field & 3.7 & 2 & 1 & 2.7 \\
Pasture & 5.3 & 2 & 2 & 5.3 \\
Forest & 7.2 & 6 & 6 & 7.2 \\
Total landholding & 29.0 & 19 & 15 & 23.6 \\
\hline
\end{tabular}

the required permits for timber harvest and transformation, or the cash loans necessary to keep the mill running in hard times. As such, the production and marketing of the fallow timber depends on complex networks of actors who maintain rural-urban identities and livelihoods. The dual knowledge base of recent urban dwellerswith their access to urban markets, and their knowledge of the location, use, and management of rural resources - is helping to drive the shift in land use and stocks of natural resources toward an emphasis on timber.

How well rural residents are able to maintain control over their resources in the face of the increasing urban demand and the expansion of their urban networks depends on the strength of demand signals, and the equitability of natural resource policy and regulation. It also will depend on their ability to adapt their production systems to new social and economic opportunities and challenges that are created by the expansion of Pucallpa and other urban centers and possible entrenchment of future rural-urban generations into purely urban living. It is clear that the maintenance of urban and rural residence and identity is helping Ucayali households build networks that allow them to find buyers for their forest and agroforest products in expanding urban markets, and that this, in turn, is affecting changes in land use in rural landholdings.

\section{CONCLUDING REMARKS: THE "URBAN FOREST"}

As we move into an "Urban Millennium," the effects of urbanward migration on rural environments will continue to be important. In this brief paper, we have attempted to show that in Amazonia neither the demographic flows nor their environmental effects are straightforward or easily summed up in numbers of people migrating, or hectares of farmland abandoned. We find that migration is an extended and complex process, not a simple event, and that the migrants, although now counted as urban residents, are often not truly absent from rural areas. We find evidence for new forms of household arrangements connecting urban and rural areas and responding to opportunities and constraints created by limited service infrastructure, employment, and global commodity markets for regional products. They frequently remain members of dispersed and multi-sited households and continue to participate in rural-urban networks and in rural land-use decisions. Despite their general poverty, the migrants affect urban markets and consumption patterns, particularly with regard to rural products, such as açaí and cheap timber. These changes have, in turn, had important and complex effects on rural landscapes: not just on the areal extent of forestswhere we find surprising increases in tree coverbut also on their composition. We find that the new urbanites' maintenance of ties to rural homes and persistence of rural preferences, tastes, and housing 
Table 3. Potential tablilla production and profits to the farmer from 1 ha of managed fallow, assuming 25 $\mathrm{cm}$ dbh commercial diameter, according to management intensity and harvest cycle.

\begin{tabular}{lccc}
\hline \hline Management level & No. commercial trees/ha & No. of tablillas & Potential profit \\
\hline Light & 200 & 4800 & $\$ 1300$ \\
Intensive, Clearcut & 500 & 12000 & $\$ 3300$ \\
Intensive, First harvest & 200 & 4800 & $\$ 1300$ \\
Second harvest & 150 & 7200 & $\$ 1800$ \\
Third harvest & 100 & 10000 & $\$ 2700$ \\
\hline
\end{tabular}

patterns, have been in some senses a "ruralization" of Amazonian cities. Households of the Amazon "urban forest," like their counterparts in Africa and Southeast Asia continue to move to cities, redefining what it is to be urban as well as rural, and thereby transforming the forests and cities of Amazonia.

Responses to this article can be read online at: http://www.ecologyandsociety.org/voll3/iss2/art2/responses/

\section{Acknowledgments:}

This paper is based on work supported by the National Science Foundation under Grant No. BCS-0527578, as well as by grants from the Overbrook Foundation to M. Pinedo-Vasquez, from the Tinker Foundation to M. Pinedo-Vasquez and R. $R$. Sears, and from the Tinker Foundation to $C$. Padoch. We also acknowledge the support of NSF Grant No. DEB-0731594. We received indispensable aid from many institutions and individuals in Brazil and Peru. We particularly would like to thank our sponsors in Brazil, the Núcleo de Altos Estudos Amazônicos of the Universidade Federal do Pará, and especially Drs. Edna Castro and David McGrath. In Peru, the Universidad Nacional de Ucayali also generously offered sponsorship. Much of the field data presented were gathered by our long-term skilled field researchers; among them we would like to especially acknowledge the work of Valois Delcastagne, Socorro Tavares, and Nathan Vogt in Brazil, and of Jino Cardenas, Medardo
Miranda, and Jim Rodriguez in Peru. We also wish to thank Louis Putzel for his perceptive editing of the text and the tables, and Chuck Peters for his expertediting of the revised manuscript. Finally, our greatest debts are owed to the many rural and urban families who have kindly shared their ideas and information with us over many years in Ponta de Pedras, Mazagão, and Ipixuna Miranda in Brazil and in Pucallpa, Contamana, and other Ucayali communities in Peru.

\section{LITERATURE CITED}

Aide, T. M., and H. R. Grau. 2004. Globalization, migration, and Latin American ecosystems. Science 305(5692):1915-1916.

Barham, B., and O. T. Coomes. 1994. Reinterpreting the Amazon rubber boom: investment, the state, and Dutch disease. Latin American Research Review 29(2):73-109.

Becker, B. K. 1985. Fronteira e urbanização repensadas. Revista Brasileira de Geografia 47 (3/4):357-371.

Becker, B. K. 1988. Significado atual da fronteira: Uma interpretação geopolítica a partir da Amazônia brasileira. Pages 60-89 in C. Aubertin, editor. Fronteiras. Universidade de Brasilia (UNB)/ ORSTOM, Brasília, Brasil. 
Becker, B. K. 2005. Geopolítica da Amazônia. Estudos Avançados 19(53):71-86.

Bierregard, R. O., C. Gason, T. E. Lovejoy, and R. Mesquita. 2001. Lessons from Amazonia: the ecology and conservation of a fragmented forest. Yale University Press, New Haven, Connecticut, USA.

Brondizio, E. S. 2006. Landscapes of the past, footprints of the future: historical ecology and the analysis of land use change in the Amazon. Pages 365-405 in W. Balée and C. Erikson, editors. Time and complexity in historical ecology: studies in the Neotropical lowlands. Columbia University Press, New York, New York, USA.

Brondizio, E.S. 2008. The Amazonian Caboclo and the Açai palm: forest farmers in the global market. New York Botanical Garden Press, New York, New York, USA.

Brondizio, E. S., C. C. M. Safar, and A. D. Siqueira. 2002. The urban market of Açaí fruit (Euterpe oleracea Mart.) and rural land use change: ethnographic insights into the role of price and land tenure constraining agricultural choices in the Amazon estuary. Urban Ecosystems 6(1/2):67-98.

Browder, J., and B. Godfrey. 1997. Rainforest cities: urbanization, development, and globalization of the Brazilian Amazon. Columbia University Press, New York, New York, USA.

David, R. 1995. Changing places: women, resource management and migration in the Sahel. SOS Sahe, London, UK.

Davis, M. 2006. Planet of slums. Verso, London, UK; New York, New York, USA.

Dufour, D. L., and B. A. Piperata. 2004. Rural-tourban migration in Latin America: an update and thoughts on the model. American Journal of Human Biology 16:395-404.

Farley, K. A. 2007. Grasslands to tree plantations: forest transition in the Andes of Ecuador. Annals of the Association of American Geographers 97:755771.

Fearnside, P. M. 2005. Deforestation in Brazilian Amazonia: history, rates and consequences. Conservation Biology 19(3):680-688.
Garcia, R. A., B. S. Soares-Filho, and D. O. Sawyer. 2007. Socioeconomic dimensions, migration, and deforestation: an integrated model of territorial organization for the Brazilian Amazon. Ecological Indicators 7(3):719-730.

Grau, H. R., T. M. Aide, J. Zimmerman, J. R. Thomlinson, E. Helmer, and X. Zou. 2003. The ecological consequences of socioeconomic and land-use changes in post-agriculture Puerto Rico. Bioscience 53(12):1159-1168.

Hecht, S. B., and S. S. Saatchi. 2007. Globalization and forest resurgence: changes in forest cover in $\mathrm{El}$ Salvador. Bioscience 57(8):663-672.

Hiraoka, M. 1994. Mudanças nos padrões econômicos de uma população ribeirinha do estuário do Amazonas. Pages 133-157 in L. Furtado, A. F. Mello, and W. Leitão, editors. Povos das Águas: Realidade e Perspectivas na Amazônia. MPEG/Universidade Federal do Para, Belém, Para, Brazil.

Instituto Brasileiro de Geografia e Estatística (IBGE). 1974-2003. Produção da Extração Vegetal $e$ da Silvicultura. Departamento Agropecuário, Diretoria de Pesquisas, Instituto Brasileiro de Geografia e Estatística, Rio de Janeiro, Brazil. [online] URL: www.ibge.gov.br.

1990. Diagnóstico Brasil: a ocupação do território e o meio ambiente. R. P. de Gusmão, editor. Fundação Instituto Brasileiro de Geografia e Estatística, Rio de Janeiro, Brazil.

_. 2007. Contagem Populacional de 2007. [online] URL: www.ibge.gov.br.

Instituto Nacional de Estadística e Informática (INEI). 2007. Censos Nacionales 2005: X de Población y V de Vivienda. [online] URL: http://ww w.inei.gob.pe/.

Kruger, F.1998. Taking advantage of rural assets as a coping strategy for the urban poor: the case of rural-urban interrelationships in Botswana. Environment and Urbanization 10(1):199-134.

Lambin, E. F., B. L. Turner, H. J. Geist, S. B. Agbola, A. Angelsen, J. W. Bruce, O. T. Coomes, R. Dirzo, G. Fischer, C. Folke, P. S. George, K. Homewood, J. Imbernon, R. Leemans, X. Li, E. F. Moran, M. Mortimore, P. S. Ramakrishnan, 
J. F. Richards, H. Skanes, W. Steffen, G. D. Stone, U. Svedin, T. A. Veldkamp, C. Vogel, and J. Xu. 2001. The causes of land-use and land cover change: moving beyond the myths. Global Environmental Change 11:261-269.

McDowell, C., and A. de Haan. 1997. Migration and sustainable livelihoods: a critical review of the literature. IDS Working Paper 65, Institute of Development Studies Brighton, UK.

Mourão, L. 1999. Do açaí ao palmito: uma história ecológica das permanencias, tensões e rupturas no estuário Amazônico. Dissertation, Núcleo de Altos Estudos Amazônicos, Universidade Federal do Para, Belém, Brazil.

Murrieta, R., D. Dufour, and A. D. Siqueira. 1999. Diet, subsistence and market in three Caboclo populations on Marajó Island, Amazonia, Brazil. Human Ecology 3:455-475.

Nugent, S. 1993. Amazonian Caboclo society: an essay on invisibility and peasant economy. Oxford University Press, Oxford, UK.

Padoch C., and M. Pinedo-Vasquez. 2006. Concurrent activities and invisible technologies: an example of timber management in Amazonia. Pages 172-180 in D. A. Posey, editor. Human Impacts on the Amazon: the role of traditional ecological knowledge in conservation and development. Columbia University Press, New York, New York, USA.

Paganoto, F. 2007. Reflexões sobre novas tendêncas migratórias no Brasil contemporâneo: a ascensão do fluxo urbano-rural. Pages 1-16 in Proceedings of the 12th Encontro Nacional da Associação Nacional de Pós-graduação e Pesquisa em Planejamento Urbano e Regional (ANPUR), 2125 May 2007, Belém, Brazil.

Perz, S. G. 2000. The quality of urban environments in the Brazilian Amazon. Social Indicators Research 49(2):181-212.

Perz, S. G., and D. L. Skole. 2003. Secondary forest expansion in the Brazilian Amazon and the refinement of forest transition theory. Society and Natural Resources 16:277-294.

Pinedo-Vasquez, M., J. Barletti Pasquale, D. Del Castillo Torres, and K. Coffey. 2002a. A tradition of change: the dynamic relationship between biodiversity and society in sector Muyuy, Peru. Environmental Science and Policy 5:45-53.

Pinedo-Vasquez, M., and C. Padoch. 2008. Urban, rural and in-between: multi-sited households, mobility and resource management in the Amazon floodplain. In M. N. Alexiades, editor. Mobility and migration in indigenous Amazonia: contemporary ethnoecological perspectives. Berghahn, Oxford, UK. (In press.)

Pinedo-Vasquez, M., C. Padoch, D. McGrath, and T. Ximenes-Ponte. 2002b. Biodiversity as a product of smallholder response to change in Amazonia. Pages 167-178 in H. Brookfield, C. Padoch, H. Parsons, and M. Stocking, editors. Cultivating biodiversity: understanding, analysing and using agricultural diversity. ITDG Publishing, London, UK.

Poullet, D. 1998. Açaí: estudo da cadeia produtiva: fruto e palmito. Instituto de Pesquisas Científicas e Tecnológicas do Estado do Amapá. Publicação avulsa, Macapá, Amapá, Brazil.

Preston, D. A. 1989. Too busy to farm: underutilisation of farm land in Central Java. Journal of Development Studies 26(1):43-57.

Rigg, J. 2002. Land, farming, livelihoods, and poverty: rethinking the links in the rural South. World Development 34(1):180-202.

Rigg, J. 2003. Evolving rural-urban relations and livelihoods in Southeast Asia. Pages 231-256 in Chia Lin Sien, editor. Southeast Asia transformed: a geography of change. Institute of Southeast Asian Studies, Singapore.

Rogez, H. 2000. Açaí: preparo, composição e melhoramento da conservação. Editora da Universidade Federal do Para, Belém, Para, Brazil.

Rudel, T. K. 2003. Tropical deforestation. Columbia University Press, New York, New York, USA.

Rudel, T. K., D. Bates, and R. Machinguiashi. 2002. A tropical forest transition? Agricultural change, out-migration, and secondary forests in the Ecuadorian Amazon. Annals of the Association of American Geographers 92(1):87-102. 
Rudel, T. K., O. T. Coomes, E. Moranc, F.Achard, A. Angelsen. J. C. Xu, and E. Lambin. 2005. Forest transitions: toward a global understanding of land use change. Global Environmental Change 15:23-31.

Santos-Granero, F., and F. Barclay. 2000. Tamed frontiers: society, and civil rights in upper Amazonia. Westview Press, Washington, D.C., USA.

Sathler, D., M. Felippe, and E. Ribeiro. 2007. As cidades médias da Amazônia Legal: uma análise comparativa dos aspectos demográficos e socioeconômicos. Pages 1-23 in Proceedings of the 12th Encontro Nacional da Associação Nacional de Pós-graduação e Pesquisa em Planejamento Urbano e Regional (ANPUR), 21-25 May 2007, Belém, Brazil.

Sears, R. R., and M. Pinedo-Vasquez. 2004. Axing the trees, growing the forest: smallholder timber production on the Amazon varzea. Pages 258-275 in D. J. Zarin, J. R. R. Alavalapatti, F. E. Putz, and M. Schmink, editors. Working forests in the Neotropics: conservation through sustainable management? Columbia University Press, New York, New York, USA.

Siqueira, A. D. 2006. Mulheres, relações de gênero e tomadas de decisão em unidades caboclas do estuário amazônico. Pages 135-236 in C. Adams, R. S. S. Murrieta, and W. A. Neves, editors. Sociedades Caboclas Amazônicas. AnaBlume/ FAPESP, São Paulo, Brazil.

Smit, W. 1998. The rural linkages of urban households in Durban, South Africa. Environment and Urbanization 10(1):77-87.

Stearman, A. M. 1985. Camba and kolla: migration and development in Santa Cruz, Bolivia. University of Florida Press, Gainsville, Florida, USA.

Strudwick, J., and G. L. Sobel. 1988. Uses of Euterpe oleracea Mart. in the Amazon estuary, Brazil. Pages 225-253 in M. Balick, editor. The palm-tree of life: biology, utilization and conservation. Advances in Economic Botany 6, New York Botanical Garden Press, New York, New York, USA.
Tacoli, C. 2002. Changing rural-urban interactions in sub-Saharan Africa and their impact on livelihoods: a summary. Working Paper Series on Rural-Urban Interactions and Livelihood Strategies. IIED, London, UK.

Tiffen, M., M. Mortimore, and F. Gichuki. 1994. More people less erosion: environmental recovery in Kenya. John Wiley, London, UK.

United Nations Population Fund (UNFPA). 2007. State of World Population 2007: unleashing the potential of urban growth. UNFPA, New York, New York, USA.

United Nations Human Settlements Programme (UN-HABITAT). 2003. The challenge of slums: global report on human settlements. UNHABITAT, New York, New York, USA.

Vicentini, Y. 2006. Cidade e História na Amazônia. Editora Universidade Federal do Paraná, Curitiba, Brazil.

Wagley, M. 1953. Amazon town: a study of man in tropics. Macmillan Company, New York, New York, USA.

Weber, J. M., and C. Sotelo Montes. 2008. Geographic variation in tree growth and wood density of Guazuma crinita Mart. in the Peruvian Amazon. New Forests 36:29-52. [online] URL: htt ps://commerce.metapress.com/content/

q5167345671q782q/resource-secured/?target=fulltext. html\&sid=z3bysz555ao10n330omea5bp\&sh=www. springerlink.com.

Weinstein, B. 1983. The Amazon rubber boom, 1850-1920. Stanford University Press, Palo Alto, California, USA.

WinklerPrins, A. M. G. A. 2002. House-lot gardens in Santarém, Para, Brazil: linking rural with urban. Urban Ecosystems 6(1-2):43-65.

WinklerPrins, A. M. G. A. 2006. Urban house-lot gardens and agrodiversity in Santarém, Pará, Brazil: spaces of conservation that link urban with rural. Pages 121-140 in K. S. Zimmer, editor. Globalization and new geographies of conservation. University of Chicago Press, Chicago, Illinois, USA. 
WinklerPrins, A. M. G. A., and P. S. de Souza. 2005. Surviving the city: urban home gardens and the economy of affection in the Brazilian Amazon. Journal of Latin American Geography 4(1):107126.

Wright, S. J., and H. C. Muller-Landau. 2006. The future of tropical forest species.Biotropica $\mathbf{3 8}$ (3):287-301. 
APPENDIX 1. Field Sites and Research Methods.

The research on which much of the data presented in this paper are based was carried out in three field research sites (see Fig. 1). Two are located in the estuary of the Amazon River: one on Marajó Island, focused on the region around the town of Ponta de Pedras in the Brazilian State of Pará, the second on the floodplains around the city of Macapá in the State of Amapá. The third is on the Ucayali and Aguaytia Rivers in the lowland Peruvian Amazon, focusing on rural sites near the town of Contamana along the Ucayali and the village of Nuevo Piura on the Aguaytia. Urban data were gathered in the following cities: Pucallpa and Yarinacocha in Peru, and Macapá, Santana, Belém and Ponta de Pedras in Brazil.

Marajó. The Marajó Island research site has been studied since 1989. Data reported on local patterns of resource management are based on systematic ethnographic surveys that began in 1990. Data on migration and land use histories are based on structured and semi-structured interviews and questionnaires applied to 129 sampled households. A strong emphasis was also placed on participant observation during this and later phases of fieldwork. All data collected were spatially referenced.

The changes reported in land use and forest composition in the Ponta de Pedras site are based on data gathered using vegetation inventories, land use histories, and experiments to measure fruit productivity under different intensities of forest management, as well as through analysis of remotely sensed images. Selection of areas for inventory was based two main factors: (1) years since management started and (2) management steps applied to the stand. Four adjacent plots (25 X 25 meters), and four randomly distributed subplots ( $5 \times 2$ meters and in some cases $10 \times 2$ meters) were distributed within the area. The total sampling area $\left(2500 \mathrm{~m}^{2}\right)$ was distributed according to spatial characteristics of açaí stands and the floodplain environment. However, in areas of unmanaged floodplain forest, the sampled area was doubled $\left(5000 \mathrm{~m}^{2}\right)$ to increase the representation of floristic and structural measurements. In these areas plots were sorted randomly into different sides of a 200-meter transect, and subplots were randomly distributed within each plot. In each plot, all tree species with dbh $10 \mathrm{~cm}$ were identified at the species level and measured for dbh, stem height (measured at the first major branch) and total height (measured at the top of the canopy). In the plots, all açaí stems with $\mathrm{dbh} \geq 5 \mathrm{~cm}$ were measured for $\mathrm{dbh}$ and total height, and number of stems per clump assessed. In each subplot, all individuals, including grasses, were identified and counted, and individuals with dbh $2 \mathrm{~cm}$ were measured for dbh and total height. The identification of plant species was done in the field (for commonly known species) and samples were collected and later identified at EMBRAPA's herbarium in Belém.

All sampled areas were geo-referenced and contributed to a multitemporal analysis of land cover change using aerial photography and satellite data. Land cover mapping and change detection was carried out for 1969, 1985, 1988, 1991, 1995, 2001. Intensively managed açaí agroforestry areas were mapped using Landsat TM, ETM, and IKONOS data coupled with intensive fieldwork and vegetation sampling. Transition matrices were used to estimate rates and direction of change between dates, including for areas of intensively managed açaí agroforestry. See Brondizio $(2006,2008)$ for more detailed descriptions of multi-temporal assessment of land cover change using remote sensing data and classification accuracy.

Experiments to measure açaí fruit productivity were carried out during the whole production season of 1994 and 1995. Experimental plots were located based on the producer's indication of the site (with its respective history) and on the analysis of area boundaries and characteristics. At each site, a 25 X 25 meter plot was marked. A subplot of 10 X 10 meters was set up inside the plot and marked in the same way. Subplot location was based on a stratified random selection.

Amapá. In the Amapá floodplain data collection began in 1994. Changes in land use were studied in seven communities in the Mazagão watershed southwest of Macapá and in five communities in Ipixuna, 
northeast of the city. Demographic, economic, and land use surveys were carried out using semistructured household interviews with 140 families in 1994, 1999, and 2006. Market surveys were conducted at various times over the last decade.

Permanent plots of one hectare were set up in twelve landholdings in each of the two floodplain areas, Mazagão and Ipixuna in 1999. Permanent plots of one hectare were also established in 12 unmanaged forests ( 6 in each site) surrounding the 24 selected landholdings. Floristic inventories of all trees $\geq 5 \mathrm{~cm}$ $\mathrm{dbh}$ in $100 \%$ of the total area of the permanent plots were carried out in the 24 selected landholdings and 12 surrounding unmanaged forests. Floristic inventories continue to be carried out every three years in all the permanent plots, measuring growth to estimate mortality and recruitment, and collecting data on productivity of extracted products.

For estimates of changes in land cover we have been using greyscale areal photographs from November 1976, Landsat TM images from July 1986, August 1992 and October 2006. Land cover mapping and change detection was carried out for 1976, 1986, 1988 and 1992 and published in a master thesis (Pereira 1998).

Peru. Research on the specific areas and issues relevant to this article began in 1999. The data cited in Tables 2 and 3 were gathered through interviews with 47 farm households with rural landholdings around the town of Contamana and from data in cadastres located in the archives found in Contamana. Floristic inventories were also conducted in 20 of those landholdings in Contamana as well as nine landholdings in Nuevo Piura along the Aguaytia River. In each of the 29 selected landholdings one hectare of forest was sampled and all trees $\geq 5 \mathrm{~cm}$ dbh were measured.

Urban data have been collected in the city of Pucallpa and neighboring Yarinacocha since 2005. Semistructured interviews were carried out with residents of about 500 households in 42 of the city's asentamientos humanos. Interviews focused on the migration history, employment history, and use of a variety of rural products including construction materials in housing. In Peru we have used Landsat TM images from July 1992 and August 2005 to build land cover maps to detect the impact of land-use changes, particularly timber extraction. 